\title{
CASE REVIEW 2 \\ DUNKIN' DONUTS ACHIEVES NOTORIETY \\ IN COLOMBIA AND WINS BATTLE \\ AGAINST COPYCAT
}

\author{
DANIELA MOLANO LOZANO*
}

\section{Case Reference}

- Resolution No. 93284 of the Superintendence of Industry and Commerce of Colombia (sic). File n. ${ }^{\circ} 15016070$

- Resolution No. 26.842of the sic, May 16, 2016

The sic declared the figurative mark with letters DUNKIN' DONUTS as a wellknown trademark in the donut's industry in Colombia, for the period of time between January 2010 and January 2015.

In the very same decision, the application for the figurative mark with letters "RICAS DONUTS DONUTS", which was filled by INDUSTRIA DE DONUTS INDUDONUTS SAS, was denied since the similarities between this and the well-known trademark DUNKIN' DONUTS could lead to confusion among consumers ${ }^{1}$.

\section{LEGAL CONTEXT}

The Decision n. ${ }^{\circ} 486$ of the Andean Community establishes the Common Industrial Property Regime for its members (Colombia, Ecuador, Perú and Bolivia), states in its Title XIII that well-known marks should be protected against unauthorized use and registration and its right holders are entitled to bring an action in order to prohibit third parties from using it, if it could cause unfair economic or commercial damage derived from the dilution of either the distinctiveness, strength, value of the mark, the prestige of the trademark or its owner ${ }^{2}$.

\footnotetext{
* Law student and Research Assistant, Intellectual Property Departament at Universidad Externado de Colombia, Bogotá, Colombia. E-mail: dani.m.lozano@hotmail.com. Dor: http://dx.doi.org/10.18601/16571959.n22.11.

1 Superindustria declara notoriedad de DUNKIN' DONUTS y niega el registro de RICAS DONUTS DONUTS | Superintendencia de Industria y Comercio. (2016). Sic.gov.co. Retrieved 10 October 2016, from http://www.sic.gov.co/drupal/noticias/superindustria-declara-notoriedad-dedunkin-donuts-y-niega-el-registro-de-ricas-donuts-donuts

2 Decision 486 (2000) The New Intellectual Property Law Of The Andean Community Intellectual Property - Colombia. (2016). Mondaq.com. Retrieved 10 October 2016, from
} 
In fact, Articles 135, 136 and 137 of the Decision 486 highlight the different scenarios in which a mark is deemed to be unregistrable, particulary relevant in the present case article 136 paragraph a) and h)

"Article 136.

Those signs may not be registered as marks whose use in trade would unduly harm a thirdparty right, especially where:

(a) they are identical or similar to a mark previously filed for registration or registered by a third party in respect of the same goods or services, or for goods or services regarding which the use of the mark could cause a risk of confusion or association;

(h) they constitute a reproduction, imitation, translation, transliteration or transcription of all or part of a well-known distinctive sign the owner of which is a third party, regardless of the goods or services to which the sign is applied, where their use would be liable to create a risk of confusion or association with that third party or with his goods or services, constitute misappropriation of the prestige of the sign or dilution of its distinctive power or commercial or advertising value." 3

\section{FACTS}

On January 27, 2015 INDUSTRIA DE DONUTS INDUDONUTS SAS filled an application for figurative mark. The mark consisted of three words, RICAS DONUTS DONUTS and the logo mark as follows:

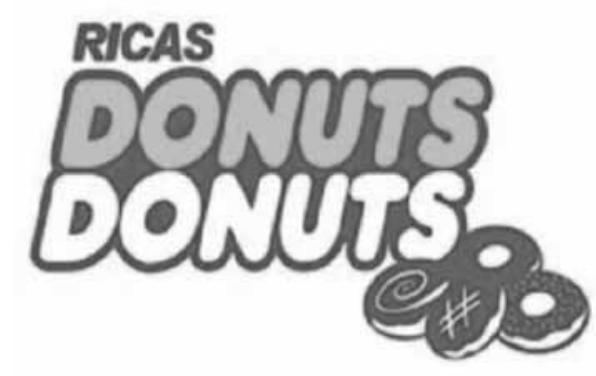

4

\footnotetext{
http://www.mondaq.com/x/11980/Decision+486+2000+The+New+Intellectual+Property+ $\mathrm{Law}+\mathrm{Of}+\mathrm{The}+$ Andean+Community

3 Andean Community: Decision No. 486 Establishing the Common Industrial Property Regime. (2016). Wipo.int. Retrieved 10 October 2016, from http://www.wipo.int/wipolex/en/text.jsp?file_id=223717

4 Superindustria declara notoriedad de DUNKIN' DONUTS y niega el registro de RICAS DONUTS DONUTS Superintendencia de Industria y Comercio. (2016). Sic.gov.co. Retrieved 10 October 2016, from http:// www.sic.gov.co/drupal/noticias/superindustria-declara-notoriedad-de-dunkin-donuts-y-niega-el-registrode-ricas-donuts-donuts
} 
The application was filled under class 30 of the Nice Classification: Bakery products; doughnuts, bread, bread rolls, biscuits, cakes and other pastries; confectionery; ices; iced confections; snacks; snack foodstuffs; coffee, tea, cocoa; sugar; sweeteners; whiteners; coatings, coverings, toppings and fillings. ${ }^{5}$

HDN DEVELOPMENT CORPORATION filled an opposition against the application. The grounds of the opposition were that the mark lacked distinctiveness, and used purely generic and descriptive terms, which according to Article 135 (b, e, I) of the Andean Decision No. 486, signs that possess such characteristics may not to be registered as marks.

DD IP HOLDER LLC, right holders of the DUNKIN' DONUT's mark, filled an opposition as well, alleging, among other things that the mark reproduces the dominant components of an already granted trademark: DUNKIN'DONUT' $s^{6}$. Additionally, the latter was also being used to distinguish products among the same class. Therefore, if the registration were granted, it would have led to confuse the purchasing public and would have directly affected DUNKIN DONUTS, thus the sign cannot be registered as a mark on the grounds established by Article $136(\mathrm{a}, \mathrm{h})$ and Article 137 of the Decision 486.

The oppositions were not responded by INDUSTRIA DE DONUTS INDUDONUTS SAs. Following Articles 146, 148 and 150 of the Decision 486, the sIC proceeded to rule whether to grant or refuse the registration of the mark.

\section{ANALYSIS}

In determining the registrability of the mark, the sic began by analyzing the arguments exhibited by the opponents, including an exhaustive comparison of the two marks.
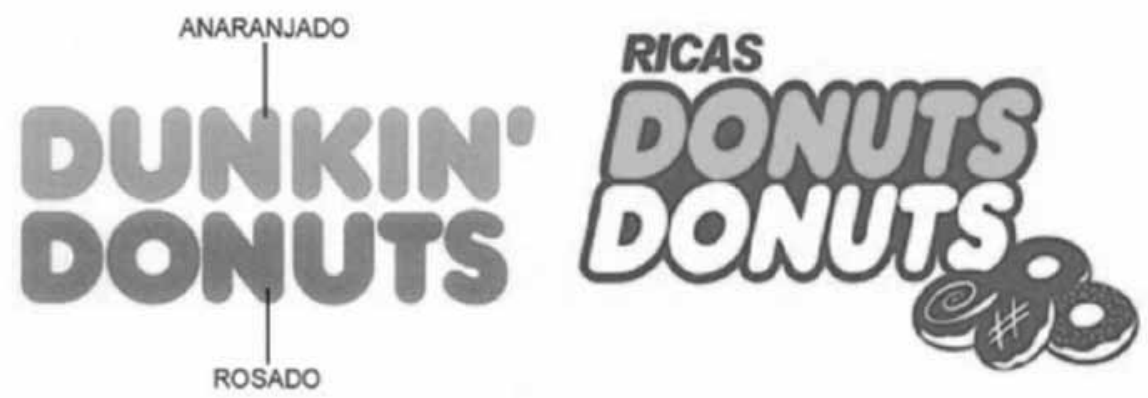

5 Clasificación de Niza. (2016). Wipo.int. Retrieved 10 October 2016, from http:// www.wipo.int/classifications/nivilo/nice/index.htm

6 Consultas Signos - sic.gov.co. (2016). Serviciospub.sic.gov.co. Retrieved 11 October 2016, from:http://serviciospub.sic.gov.co/Sic/ConsultaEnLinea/2013/RegistroSignos.php?zaqwscersderwerrteyr=pol\%F 1 mkjuiutdrsesdfrcdfds\&qwx=ltjS0sLc2L2gbWRomqaikw== 
The sIC came to the conclusion that even though there were differences in the nominative element of the mark, there are strong similarities in the graphic elements, such as the font used, the color scheme (magenta, orange and white) and the disposition of the words. It was not just about the concurrence of the use of the word DONUTs, but also a mound of coincidences. Consequently, both marks are unable to coexist in the market without creating risk of confusion among consumers, regarding the origin of the product, because there is an evident competitive connection and similar channels of marketing and distribution.

As the opponent also attached evidence to prove the notoriety of the mark, the sIC, taking into consideration the factors to determine notoriety of a distinctive sign unveiled on Article 228 of the Decision 486 found that DUNKIN' DONUTS was a well-known mark in Colombia due to their economical effort and response from the consumers, i.e. its participation in the Colombian market since 1982 and almost 200 stores in the Country; hence, the applicant was misappropriating the prestige of the opponent's mark. ${ }^{7}$

Lastly, when analyzing Article 137 of the Decision 486, ${ }^{8}$ the sIC concludes that if the registration ever took place, it would have facilitated or consolidated an act of unfair competition as the sign was being employed on their products and complementary elements (napkins/boxes/web page), hence, the solicitant had always been aware of the existence and magnitude of the DUNKIN DONUT's mark in the territory, which evidences the applicant's lack of good faith.

Following the analysis exposed, the authority decided to deny the registration of the applicant's mark.

The decision was appealed by the applicant INDUSTRIA DE DONUTS INDUDONUTS SAS arguing that the national authority had not taken into account that the mark was distinctive enough to lead to confusions among consumers. Another argument upheld was that both marks had been coexisting in the Colombian market for more than a decade without obstacle.

The sIC once again took into consideration the parameters and probatory material filed by the opponent, and it uphold the previous decision, i.e. DUNKIN DONUTS is a well-known mark in Colombia in the period comprehended between the years 2010 and 2015, since the mark has a proven recognition in the relevant sector of the public, it has been present in the national territory for a prolonged time, and has presence in a large extension of the territory. It was also evaluated other matters such as: the successful enforcement of the mark by DUNKIN' DONUTS, the fact that the right holder had invested more than 3.000.000 million pesos in

7 Andean Community: Decision No. 486 Establishing the Common Industrial Property Regime. (2016). Wipo.int. Retrieved 10 October 2016, from http://www.wipo.int/wipolex/en/ text.jsp?file_id=223717 On the grounds of Article 228, 229 and 230 of the Decision 486.

8 Ibid. "137. Where the competent national office has reasonable grounds to believe that registration has been applied for in order to perpetrate, facilitate or consolidate an act of unfair competition, it may refuse registration." 
publicity between the years 2010 and 2014, and made sales over 260.000.000 million pesos during the same period of time in the national territory.

It was also confirmed that the applicant's sign, when used on the identified services, was likely to create confusion with opponent's previously granted DUNKIN' DONUTS mark, which had also achieved notoriety.

\section{PRACTICAL SIGNIFICANCE}

The ruling adds up to a series of similar cases on well-known marks such as Starbucks and Mac Donald's ${ }^{9}$ which have recently taken place in Colombia, indicator that right holders of well-known marks often faces problems to obtain international protection for such marks making ownership of these marks a high-maintenance business ${ }^{10}$.

This series of cases on well-known marks constitute a relief for the right holders of this kind of marks taking into consideration that they are currently primary targets for specific forms of illegal activities that society does not condemn, and to some extent, actually embraces. ${ }^{11}$ It's a satisfactory decision that effectively protects Dunkin Donut's rights in our country. A mark which has been present in our country for more than three decades, and is continuously making countless efforts in order to maintain the mark's position and good will in Colombia.

9 Information of the cases available:

Superintendencia de Industria y Comercio protege la notoriedad de la marca STARBUCKS Superintendencia de Industria y Comercio. (2016). Sic.gov.co. Retrieved 10 October 2016, from http://www.sic.gov.co/drupal/noticias/superintendencia-de-industria-y-comercioprotege-la-notoriedad-de-la-marca-starbucks

Dooglas, L. (2015). La dura batalla entre McDonald's y Mac Dooglas. Semana.com. Retrieved 10 October 2016, from http://www.semana.com/nacion/articulo/la-dura-batallaentre-mcdonalds-mac-dooglas/441635-3

10 Lehrman, R. \& Cucurella, C. International Protection of Well-Known Marks. Frosszelnick. Retrieved 10 October 2016, from http://www.frosszelnick.com/sites/default/ files/20061017163104_1_PUBLISHED_PDF_0.pdf

11 Ibid. 